\title{
Impact of varietal feeding of eight Mulberry varieties on Bombyx mori L.
}

\author{
S. K. Gangwar \\ Department of Applied Animal sciences, \\ Babasaheb Bhimrao Ambedkar University (A Central University), \\ Vidya Vihar, Raebareli Road, Lucknow-226025, Uttar Pradesh, India.
}

\begin{abstract}
The eight improved mulberry varieties i.e. $\mathrm{S}_{146}, \mathrm{~K}_{2}, \mathrm{~S}_{1635}, \mathrm{AR}_{14}, \mathrm{TR}_{10}, \mathrm{BR}_{2}, \mathrm{~S}_{1}$ \& $\mathrm{AR}_{12}$ were introduced in mulberry garden of Department of Applied Animal Sciences and theses varieties were evaluated for nutritional potential by feeding experiments. Weighted quantities of leaves of each variety were fed to mulberry silkworms and data were collected and evaluted. The larvae feeding on $\mathrm{BR}_{2}$ leaves were observed the higher weight of mature larvae and showed improved economic traits i.e. cocoon weight, shell weights and silk percentage in comparision to other varieties.
\end{abstract}

Keywords: varieties, Bombyx mori,

\section{INTRODUCTION}

Mulberry silkworm (Bombyx mori L.) sustains its nutrition from its food plants of different species of Morus. The nutritional levels of different cultivars of mulberry influence the larval growth of silkworm, which ultimately influence the economic traits - such as yield, cocoon, shell weight and silk percentage of silkworm. The present study has been started to make a comparative evaluation of all the popular varieties of mulberry with regard to the food utilization by larvae and ultimate impact on the cocoon traits of silkworm so as to spot out the most nutritive one for bivoltine silkworm in Uttar Pradesh climatic conditions.

Studies on the biochemical composition of different mulberry varieties have been conducted in Japan by Suzuki (1926), while the influence of mulberry leaf of different varieties on larval behavior and cocoon traits of silkworm was studied by Narayanan et al., 1966; Chawla, 1970; Krishnaswami et al., 1970, 1971; Pillai and Jolly, 1985 in tropical climatic zones of India. On the other hand Sudo, 1979 \& 1981; Joshi, 1984 \& 1985; Periasamy et al., 1984 \& 1985; Narayananprakash, et al., 1985 and Pant, et al., 1986 conducted work on the food utilization by silkworm B. mori L. and silk moth Philosamia ricini Hutt. in India and abroad. However, no work has been carried out on the aforementioned varieties in India.

\section{MATERIALS AND METHODS}

The present study has been conducted at Department of Applied Animal Sciences, Babasaheb Bhimrao Ambedkar University, Lucknow. The eight improved cultivars of mulberry varieties i.e. $\mathrm{S}_{146}, \mathrm{~K}_{2}$, $\mathrm{S}_{1635}, A R_{14}, \mathrm{TR}_{10}, \mathrm{BR}_{2}, \mathrm{~S}_{1} \& \mathrm{AR}_{12}$ were selected as food for a hybrid silkworm $\mathrm{SH}_{6} \times \mathrm{NB}_{4} \mathrm{D}_{2}$ in three rearing seasons during 2006. Five layings of the hybrid were brushed as individual cells. Each treatment was given leaves of specific variety four times daily the rearing was done as per the established procedure. After 3rd moult 400 larvae, each replicated thrice were taken under each treatment and fed with weighed quantity of leaves of each variety, One of the treatments with mixed leaves of all eight varieties was taken as the control. At the end of each feed the left over leaves along with faeces were weighed. The loss in moisture during feeding time was calculated from a dummy of the same quantity of leaves kept separate in the rearing room. From this the feed consumed and faeces voided by the worms in the rearing bed were calculated; the average weight of larvae during feeding and gain in larval weight at the maturity, larval mortality, Yield/10000 larvae-by No., Yield/10000 larvae-by wt. (kg.), Survival rate of pupae (\%), Single cocoon wt. (g), Single shell wt. (cgm) and Shell ratio (\%) were recorded after each feed in three seasons i.e. spring, summer and autumn and data was statically arranged in Table -1 and graph-1 to 6 .

\section{RESULTS AND DISCUSSION}

The results are presented in Table-1. The data recorded, in terms of fresh weight of the test animal and cocoon features reveals as under:

The results recorded for all the other parameters (Table 1 ) in the three rearing are non-significant, yet the performance of larvae was better under the influence of $\mathrm{BR}_{2}$ leaves. The percentage mortality of larvae fed with $\mathrm{BR}_{2}$ leaves was low in summer and autumn and high in spring season in comparison to other treatments while in spring $\mathrm{BR}_{2}$ followed $\mathrm{TR}_{10}$ and $S_{146}$. The yield of 10,000 larvae by number was 
highest in case of larvae fed on $\mathrm{BR}_{2}, \mathrm{TR}_{10}$ and $\mathrm{AR}_{14}$ leaves during spring, autumn and summer rearings, respectively; while the yield by weight being highest in case $B R_{2}, T R_{10}$ and $A R_{14}$ treatments during spring, autumn and summer seasons respectively. The single cocoon weight was recorded highest in $\mathrm{BR}_{2}$, $\mathrm{AR}_{14}$ and Mixed treatment during spring, autumn and summer seasons. The shell weight was observed to be highest in the cocoons

harvested under $\mathrm{BR}_{2}$ treatment during all seasons rearings, The shell ratio was found to be best in the cocoons harvested from the $\mathrm{BR}_{2} \mathrm{TR}_{10}$ and $\mathrm{AR}_{14}$ treatments during spring, autumn and summer

Table -1 Impact of varietal feeding on cocoon characters rearing seasons .To conclude it is established that the ingesta, faeces voided and consumption index were low for the larvae reared on $\mathrm{BR}_{2}$ leaves, while the growth rate and approximate digestibility was high in the larvae fed with $\mathrm{BR}_{2}$ leaves. The efficiency of conversion of ingested and digested food into the body matter was also high in larvae fed with $\mathrm{BR}_{2}$ leaves. On the other hand, the single cocoon weight, shell weight and shell ratio were found higher in the worms, which fed under the influence of $\mathrm{BR}_{2}$ leaves. Furthermore, the ingesta /larva being low for the worms reared on $\mathrm{BR}_{2}$ leaves, it is possible to rear increased number of silkworm larvae within a unit quantity of leaf.

\begin{tabular}{|c|c|c|c|c|c|c|c|c|c|c|c|}
\hline Parameter & Season & $\mathrm{S}_{146}$ & $\mathrm{~K}_{2}$ & $\mathbf{S}_{1635}$ & $\mathrm{AR}_{14}$ & $\mathrm{TR}_{10}$ & $\mathrm{BR}_{2}$ & $\mathbf{S}_{1}$ & $\mathrm{AR}_{12}$ & Mixed & $\begin{array}{l}\text { C.D. } \\
5 \%\end{array}$ \\
\hline $\begin{array}{l}\text { Wt. of } 10 \\
\text { matured } \\
\text { larvae }\end{array}$ & $\begin{array}{l}\text { Spring } \\
\text { Summer } \\
\text { Autumn }\end{array}$ & $\begin{array}{l}50.54 \\
33.56 \\
43.52\end{array}$ & $\begin{array}{l}49.52 \\
33.12 \\
42.58\end{array}$ & $\begin{array}{l}49.45 \\
33.00 \\
42.15\end{array}$ & $\begin{array}{l}49.15 \\
33.70 \\
42.00\end{array}$ & $\begin{array}{l}50.90 \\
34.42 \\
43.78\end{array}$ & $\begin{array}{l}51.00 \\
35.56 \\
44.52\end{array}$ & $\begin{array}{l}48.94 \\
33.89 \\
43.74\end{array}$ & $\begin{array}{l}49.12 \\
34.00 \\
43.10\end{array}$ & $\begin{array}{l}49.94 \\
33.20 \\
43.85\end{array}$ & $\begin{array}{l}\text { N.S. } \\
2.89 \\
1.21\end{array}$ \\
\hline $\begin{array}{l}\text { Larval } \\
\text { mortality }\end{array}$ & $\begin{array}{l}\text { Spring } \\
\text { Summer } \\
\text { Autumn }\end{array}$ & $\begin{array}{l}0.45 \\
18.52 \\
3.30 \\
\end{array}$ & $\begin{array}{l}0.50 \\
19.56 \\
3.27 \\
\end{array}$ & $\begin{array}{l}0.82 \\
21.45 \\
4.56 \\
\end{array}$ & $\begin{array}{l}0.56 \\
14.58 \\
5.87 \\
\end{array}$ & $\begin{array}{l}0.64 \\
12.80 \\
4.00 \\
\end{array}$ & $\begin{array}{l}0.33 \\
10.45 \\
2.15 \\
\end{array}$ & $\begin{array}{l}0.80 \\
21.50 \\
2.80 \\
\end{array}$ & $\begin{array}{l}0.59 \\
19.85 \\
3.45 \\
\end{array}$ & $\begin{array}{l}0.68 \\
16.85 \\
4.25 \\
\end{array}$ & $\begin{array}{l}\text { N.S. } \\
\text { N.S. } \\
\text { N.S. }\end{array}$ \\
\hline $\begin{array}{l}\text { Yield/10000 } \\
\text { larvae-by No. }\end{array}$ & $\begin{array}{l}\text { Spring } \\
\text { Summer } \\
\text { Autumn }\end{array}$ & $\begin{array}{l}90.92 \\
78.56 \\
88.90\end{array}$ & $\begin{array}{l}90.56 \\
77.80 \\
89.51\end{array}$ & $\begin{array}{l}90.50 \\
78.12 \\
85.52\end{array}$ & $\begin{array}{l}92.54 \\
80.45 \\
88.45\end{array}$ & $\begin{array}{l}93.75 \\
80.65 \\
94.58\end{array}$ & $\begin{array}{l}94.50 \\
85.80 \\
95.42\end{array}$ & $\begin{array}{l}89.90 \\
76.56 \\
91.56\end{array}$ & $\begin{array}{l}91.78 \\
79.12 \\
89.50\end{array}$ & $\begin{array}{l}91.45 \\
85.56 \\
90.45\end{array}$ & $\begin{array}{l}\text { N.S. } \\
\text { N.S. } \\
\text { N.S. }\end{array}$ \\
\hline $\begin{array}{l}\text { Yield/10000 } \\
\text { larvae-by wt. } \\
\text { (kg.) }\end{array}$ & $\begin{array}{l}\text { Spring } \\
\text { Summer } \\
\text { Autumn }\end{array}$ & $\begin{array}{l}14.90 \\
12.56 \\
14.23\end{array}$ & $\begin{array}{l}13.58 \\
12.82 \\
14.00\end{array}$ & $\begin{array}{l}13.95 \\
11.96 \\
13.45\end{array}$ & $\begin{array}{l}14.12 \\
12.66 \\
13.90\end{array}$ & $\begin{array}{l}14.85 \\
13.00 \\
15.00\end{array}$ & $\begin{array}{l}16.35 \\
13.89 \\
15.90\end{array}$ & $\begin{array}{l}13.86 \\
11.80 \\
14.10\end{array}$ & $\begin{array}{l}12.56 \\
11.54 \\
13.00\end{array}$ & $\begin{array}{l}13.56 \\
12.65 \\
13.46\end{array}$ & $\begin{array}{l}\text { N.S. } \\
\text { N.S. } \\
\text { N.S. }\end{array}$ \\
\hline $\begin{array}{l}\text { Survival rate } \\
\text { of pupae }(\%)\end{array}$ & $\begin{array}{l}\text { Spring } \\
\text { Summer } \\
\text { Autumn }\end{array}$ & $\begin{array}{l}94.52 \\
91.65 \\
93.45\end{array}$ & $\begin{array}{l}94.60 \\
90.56 \\
95.00\end{array}$ & $\begin{array}{l}93.89 \\
90.56 \\
94.00\end{array}$ & $\begin{array}{l}94.52 \\
89.90 \\
93.80\end{array}$ & $\begin{array}{l}95.60 \\
90.50 \\
94.58\end{array}$ & $\begin{array}{l}97.48 \\
94.50 \\
96.80\end{array}$ & $\begin{array}{l}93.54 \\
89.42 \\
94.00\end{array}$ & $\begin{array}{l}92.45 \\
92.57 \\
94.68\end{array}$ & $\begin{array}{l}94.80 \\
90.96 \\
95.15\end{array}$ & $\begin{array}{l}1.51 \\
\text { N.S. } \\
\text { N.S }\end{array}$ \\
\hline $\begin{array}{l}\text { Single } \\
\text { cocoon wt. } \\
(\mathrm{g})\end{array}$ & $\begin{array}{l}\text { Spring } \\
\text { Summer } \\
\text { Autumn }\end{array}$ & $\begin{array}{l}1.80 \\
1.64 \\
1.72 \\
\end{array}$ & $\begin{array}{l}1.85 \\
1.62 \\
1.89 \\
\end{array}$ & $\begin{array}{l}1.87 \\
1.72 \\
1.91 \\
\end{array}$ & $\begin{array}{l}1.94 \\
1.75 \\
1.90 \\
\end{array}$ & $\begin{array}{l}1.91 \\
1.76 \\
1.89 \\
\end{array}$ & $\begin{array}{l}1.94 \\
1.91 \\
1.94 \\
\end{array}$ & $\begin{array}{l}1.92 \\
1.68 \\
1.79 \\
\end{array}$ & $\begin{array}{l}1.89 \\
1.71 \\
1.85 \\
\end{array}$ & $\begin{array}{l}1.92 \\
1.75 \\
1.86 \\
\end{array}$ & $\begin{array}{l}\text { N.S. } \\
\text { N.S. } \\
\text { N.S. }\end{array}$ \\
\hline $\begin{array}{l}\text { Single shell } \\
\text { wt. (cgm) }\end{array}$ & $\begin{array}{l}\text { Spring } \\
\text { Summer } \\
\text { Autumn }\end{array}$ & $\begin{array}{l}36.89 \\
32.56 \\
34.78 \\
\end{array}$ & $\begin{array}{l}37.52 \\
31.56 \\
37.00 \\
\end{array}$ & $\begin{array}{l}38.42 \\
32.80 \\
38.00 \\
\end{array}$ & $\begin{array}{l}39.23 \\
33.41 \\
38.92 \\
\end{array}$ & $\begin{array}{l}40.12 \\
35.25 \\
39.45 \\
\end{array}$ & $\begin{array}{l}42.78 \\
38.45 \\
41.00 \\
\end{array}$ & $\begin{array}{l}37.25 \\
32.56 \\
35.22 \\
\end{array}$ & $\begin{array}{l}36.45 \\
32.78 \\
33.56 \\
\end{array}$ & $\begin{array}{l}38.46 \\
34.41 \\
36.60 \\
\end{array}$ & $\begin{array}{l}\text { N.S. } \\
2.31 \\
\text { N.S. }\end{array}$ \\
\hline $\begin{array}{l}\text { Shell ratio } \\
(\%)\end{array}$ & $\begin{array}{l}\text { Spring } \\
\text { Summer } \\
\text { Autumn }\end{array}$ & $\begin{array}{l}20.47 \\
19.87 \\
20.25\end{array}$ & $\begin{array}{l}20.28 \\
19.50 \\
19.59\end{array}$ & $\begin{array}{l}20.54 \\
18.73 \\
19.90\end{array}$ & $\begin{array}{l}20.23 \\
19.10 \\
20.48\end{array}$ & $\begin{array}{l}21.00 \\
20.02 \\
20.87\end{array}$ & $\begin{array}{l}21.39 \\
20.13 \\
21.13\end{array}$ & $\begin{array}{l}19.40 \\
19.38 \\
19.67\end{array}$ & $\begin{array}{l}19.28 \\
19.16 \\
21.24\end{array}$ & $\begin{array}{l}20.03 \\
19.66 \\
19.68\end{array}$ & $\begin{array}{l}\text { N.S. } \\
\text { N.S. } \\
\text { N.S. }\end{array}$ \\
\hline
\end{tabular}

Graph-1 Weight of 10 mature larvae (g)

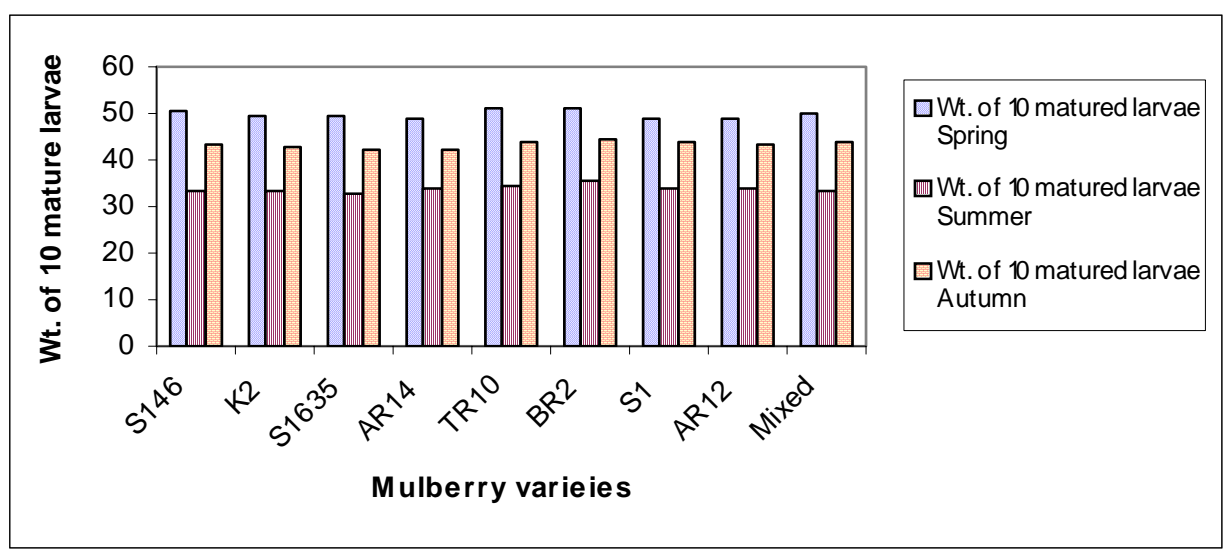


Agric. Biol. J. N. Am., 2010, 1(3): 350-354

Graph-2 Larval Mortality in different seasons

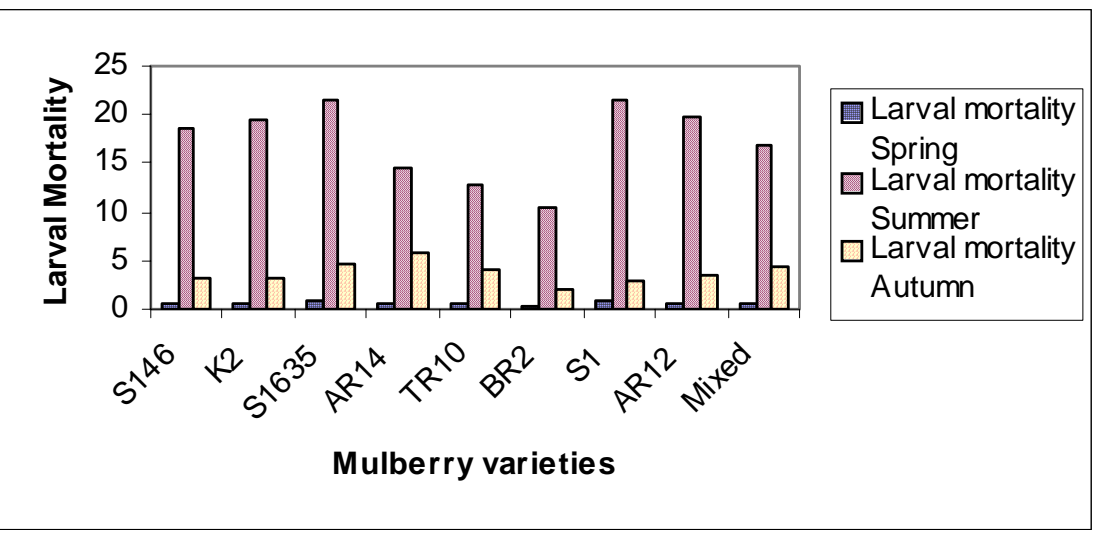

\section{Graph-3}

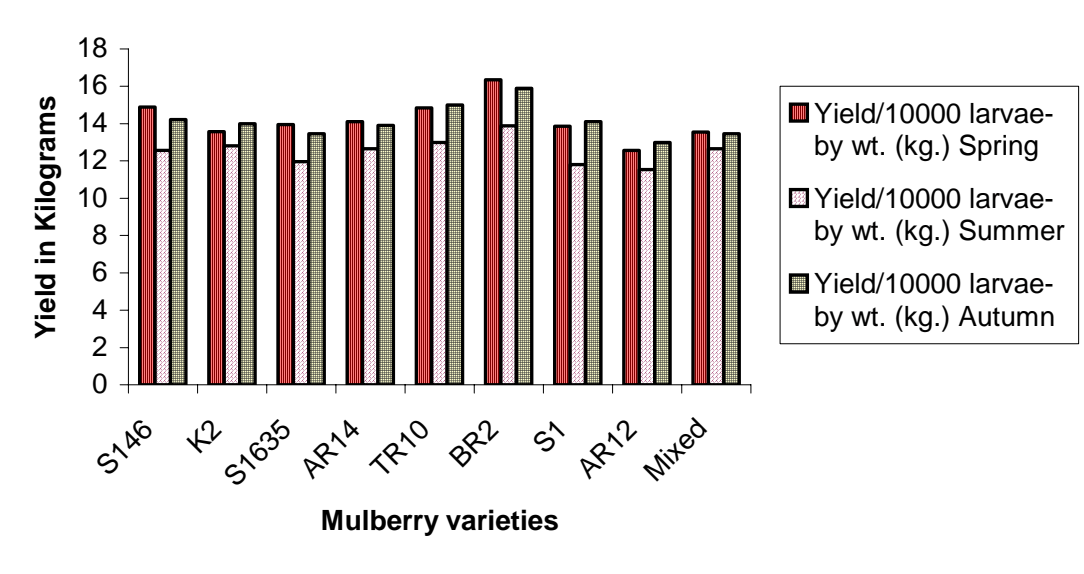

\section{Graph -4}

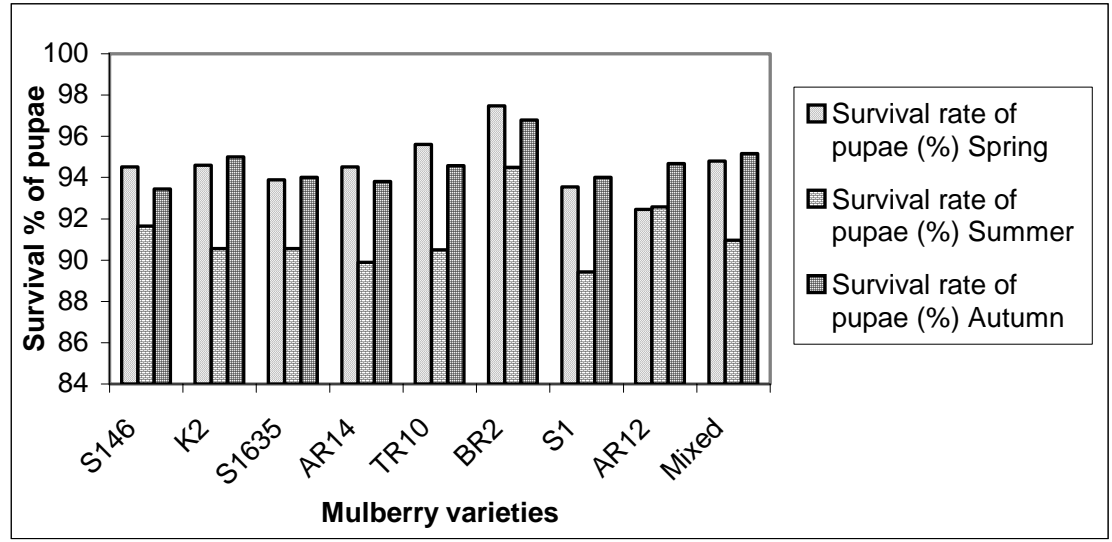


Agric. Biol. J. N. Am., 2010, 1(3): 350-354

\section{Graph -5}

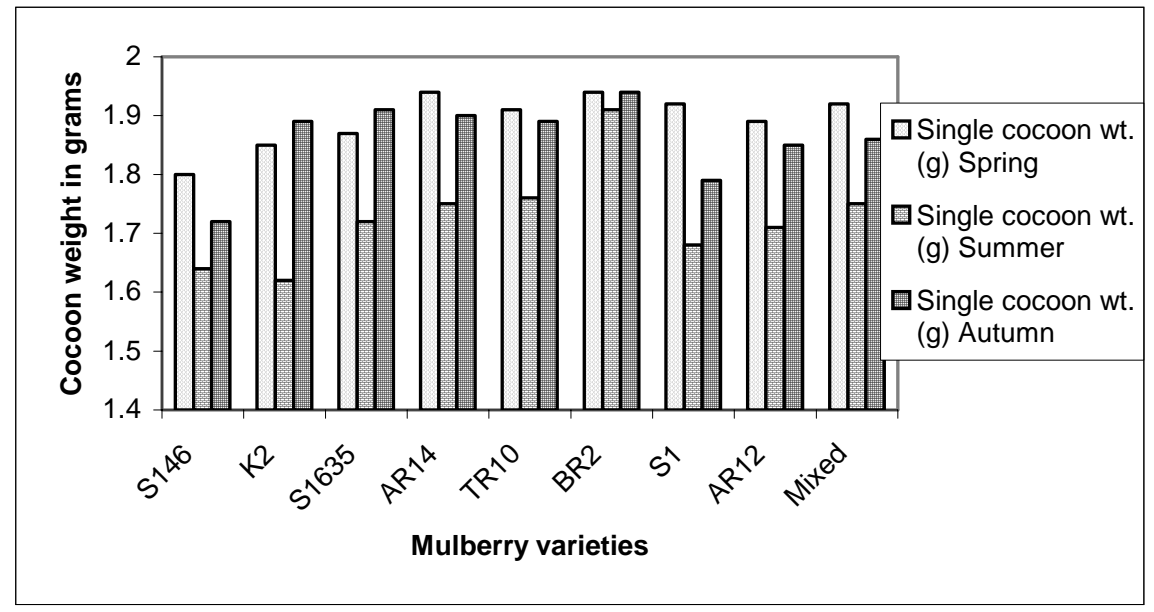

\section{Graph -6}

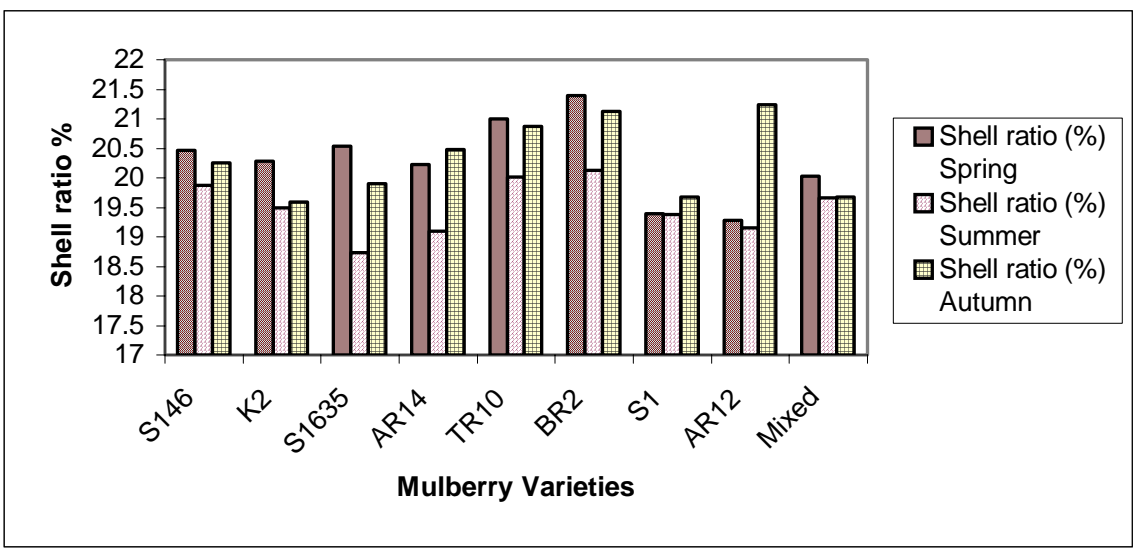

\section{REFERENCES}

Chawla, S.S. (1970) Effect of feeding different kinds of leaves on the growth and development of the larvae in the new multivoltine silkworm race, "Mysore Princess". Revue Du Ver A Soie Special ed., June.

Joshi, K.L. (1984) Sex specific consumption and utilization of food by Eri silk moth, Philosamia ricini Hutt. (Lep.: saturniidae). Sericologia.24:21.24.

Joshi, K. L. (1985a) Relationship between food consumption and fecundity of Eri silkmoth, Philosamia ricini, Hutt. (Lep.: Saturniidae). Ibid., 25: 301-305.

Joshi, K. L. (1985b) Studies on the growth indices for "Eri silkmoth, Philosamia ricini Hutt. Ibid., 25: 313-319.

Krishnaswami, S., Noamani, K.R. and Asan, M. (1970) Studies on the quality of mulberry leaves and silkworm crop production. 1. Quality differences due to varieties. Indian. J. Seric., 9:1-10.
Krishnaswami, S., Kumarraj, S., Vijayaragavan, K. and kasiviswanathan, K. (1971) Silkworm feeding trails for evaluating mulberry leaves as influenced by variety, spacing and nitrogen fertilization. Ibid. 5: 13-17.

Narayan, E.S.; Kasiviswanathan, K. and lyengar, M.N.S. (1966) Effect of varietal feeding, irrigation levels and nitrogen fertilization on larval development and cocoon characters of Bombyx mori L. Ibid. 5:13-17.

Narayanan Prakesh, R., Periasamy, K. and Radhakrishanan, S. (1985) Effect of dietary water content on food utilization and silk production in Bombyx mori L. (Lepidoptera: Bombycidae). Indian J. Seric., 24: 49-54.

Pant, Radha Ramana, D. and Sarkar, A. (1986) Consumption and utilization of feed in Philosamia ricini larva during development. Sericologia, 26: 49-54.

Periasami, K., Narayanprakash, R. and Radhakrishnan, S. (1984) Food utilization in exotic and indigenous races 
Agric. Biol. J. N. Am., 2010, 1(3): 350-354

of Bombyx mori L. (Lep.:Bombycidae). Sericologia, 24:43-50

Periasamy,K. and Radhakrishanan, S. (1985) A quantitative study of food utilization and silk production in Bombyx mori L. for evaluation of superior varieties of mulberry. Ibid. 25: 491-500.

Sudo, Makoto, Sho, Yorio and Okajima, Teruo (1979) The relation between the leaf quality at different leaf order and silkworm growth and cocoon quality (1). Jour. Seri. Sci. Jpn., 48: 439-443.

Sudo, Makoto, Sho, Yorio and Okajima, Teruo (1981) The relation between the leaf quality at different leaf order and silkworm growth and cocoon quality (2). Ibid. 50: 306-310.

Suzuki (1926) Chemical composition of mulberry leaves and mulberry races. Textbook of Tropical Sericulture, Japan. Overseas Co-operation Volunteers, Tokyo, Japan.

Venugopala Pillai, S.V. and Jolly, M.S. (1985) An evaluation on the quality of mulberry varieties raised under hill conditions and the crop results of Bombyx mori (L). Ind. J. Sreic .,Vol. 24(2):48-52. 